\title{
Weeds associated with cotton crop and hosting whitefly
}

\section{Plantas daninhas associadas à cultura do algodoeiro e hospedeiras de mosca-branca}

\author{
Sandra Rodrigues ${ }^{*}$ (D), Alexandre Ferreira Silva ${ }^{2}$

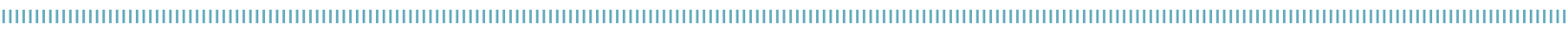

\begin{abstract}
The whitefly can be hosted by weeds and cause damage to cotton crops. The objective of this work was to identify which species of weeds among the floristic compositions occurring in the cotton crop are hosts of whiteflies (Bemisia tabaci biotype B). Bi-weekly evaluations were performed in a cotton area (FM 975 WS) in Sinop, Mato Grosso, Brazil, during the reproductive phase of the crop. An inventory square $(0.25 \mathrm{~m}$ side) was randomly cast 15 times between the cotton rows. The weeds were cut close to the ground, conditioned and taken to the laboratory to identify the family and species, and to quantify the eggs and nymphs of whiteflies. Eleven families were detected, with the most frequent being Amaranthaceae (16.67\%), Convolvulaceae (12.5\%), Rubiaceae (12.5\%) and Poaceae (12.5\%). The most frequent species were Amaranthus spp. (13.79\%) and Alternanthera tenella, Ipomea spp., Richardia brasiliensis and Eleusine indica, with $10.34 \%$ each. From the 15 collected species, the presence of whitefly eggs or nymphs was only not observed in Portulaca oleracea and E. indica. The highest incidence of B. tabaci occurred in Euphorbia heterophylla. The occurrence of these species should be monitored, so that the whitefly population does not interfere in the cotton fiber quality.
\end{abstract}

KEYWORDS: infestation; crop management; Bemisia tabaci; host plants.
RESUMO: A mosca-branca pode hospedar-se em plantas daninhas e causar prejuízos ao algodoeiro. O objetivo deste trabalho foi identificar, entre a composição florística de plantas daninhas que ocorrem na cultura do algodoeiro, quais são hospedeiras da mosca-branca (Bemisia tabaci biótipo B). Em uma área de algodoeiro (FM 975 WS) em Sinop, Mato Grosso, Brasil, foram feitas avaliações quinzenais na fase reprodutiva da cultura. Um quadrado inventário $(0,25$ $\mathrm{m}$ de lado) foi lançado aleatoriamente 15 vezes nas entrelinhas do algodoeiro. As plantas daninhas foram cortadas rente ao solo, acondicionadas e levadas para o laboratório para identificação da família e da espécie, quantificação dos ovos e ninfas de mosca-branca. Foram detectadas 11 famílias, sendo as mais frequentes Amaranthaceae (16,67\%), Convolvulaceae (12,5\%), Rubiaceae (12,5\%) e Poaceae (12,5\%). As espécies mais frequentes foram Amaranthus spp. (13,79\%) e Alternanthera tenella, Ipomea spp., Richardia brasiliensis e Eleusine indica, com 10,34\% cada uma. Das 15 espécies coletadas, apenas em Portulaca oleracea e E. indica não foi constatada a presença de ovos ou ninfas de mosca-branca. A maior incidência de B. tabaci ocorreu em Euphorbia heterophylla. A ocorrência dessas espécies deve ser monitorada para que a população de mosca-branca não interfira na qualidade da fibra do algodoeiro.

PALAVRAS-CHAVE: infestação; manejo; Bemisia tabaci; plantas hospedeiras. 
Weeds are among the biotic factors that affect agricultural systems, affecting their productivity by reducing yield and product quality. Among the weeds that compete with the cotton plant, there are Amaranthus spp., Alternanthera tenella, Bidens spp., Commelina benghalensis, Digitaria insularis, Eleusine indica, Ipomoea spp., Portulaca oleracea, Richardia brasiliensis, and Sida spp. (CHRISTOFFOLETI et al., 2011).

According to YAMASHITA et al. (2008), controlling limiting factors such as weeds is fundamental, so that the crop can express its full productive potential. Since weeds compete for water, light and nutrients, the cotton must remain free of these plants for a good part of its cycle in order to avoid weed competition, the proliferation of pests and diseases and to guarantee the quality of the plume produced (CHRISTOFFOLETI et al., 2011). Inadequate weed management can lead to losses in income greater than 90\% (RAIMONDI et al., 2014). During the cotton cycle, weeds not only compete for environmental resources (water, light and nutrients), but also alternative hosts for viruses and various pest arthropods capable of attacking this crop. Sida rhombifolia (arrowleaf sida) and Scaphyglottis micrantha (orchid) species host the virus that causes the common mosaic virus (Abutilon mosaic virus) transmitted by the Bemisia tabaci biotype B whitefly (SUASSUNA; COUTINHO, 2015).

Whitefly adults and nymphs settle on the underside of the cotton leaves to feed themselves. The insects suck large volumes of phloem sap, rich in sucrose, but they have low concentrations of essential amino acids (TERRA; FERREIRA, 2009). Amino acids are important for performing the insect's physiological processes and need to be concentrated. For this, excess water is withdrawn by the filter chamber present in its digestive system and excreted along with sugars in the form of mela, which is deposited on the cotton leaves or plume. This substance is used as a substrate for growing saprophytic fungi such as Capnodium, followed by the fumagine that reduces the photosynthetic area of the leaves. Both honeydew and sooty mold contaminate the fiber and reduce its quality, rendering it unsuitable for the textile industry. ARAÚJO; BLEICHER (2004) report that the crop's critical period to attack from whiteflies is starting from the emergence of the plants until the appearance of the first buds.

When thinking about structuring a whitefly management plan, it is important to know its interaction with the alternative hosts in the field. Thus, the objective of this work was to identify which species of weeds among the floristic compositions occurring in the cotton crop are host of whitefly (B. tabaci biotype B).

The experiment was carried out in a commercial area of three hectares planted with FM 975 WS cotton cultivar on September $1^{\text {st }}, 2015$, in the municipality of Sinop, Mato Grosso,

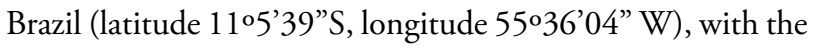
altitude of $335 \mathrm{~m}$. The soil of the experimental area was classified as dystrophic red-yellow latosol (SANTOS et al., 2006).
The evaluations of whitefly presence in the weeds were done biweekly in the period from April to June, which corresponds to the reproductive crop phase.

A square of $0.25 \mathrm{~m}$ per side was used to inventory the plants and released 15 times between the cotton rows. The weeds were cut close to the ground, placed in sacks of craft paper, which were then packed in a styrofoam box and taken to the cold chamber of the Brazilian Agricultural Research Corporation (Embrapa) Agrosilvipastoral entomology laboratory.

The plants were identified by comparing the botanical characteristics of each specimen with those described in the literature by MOREIRA; BRAGANÇA (2010) and LORENZI (2014). For each family and species present, we calculated the frequency and relative frequency of the weed community according to MUELLER-DOMBOIS; ELLEMBERG (1974). After identification, the whitefly eggs and nymphs present in the weeds were quantified. All leaves were observed by means of an optical microscope with a magnification of 20 times. The total values of eggs and nymphs were used to construct the whitefly fluctuation in the different weed species during the sampling months.

The weed infestation community collected in the cotton crop was composed of 11 families, with 81.8 and 18.2\% belonging to the Magnoliopsida and Liliopsida classes, respectively. There were the following families from the Magnoliopsida class: Amaranthaceae, Asteraceae, Convolvulaceae, Euphorbiaceae, Fabaceae, Portulacaceae, Rubiaceae, Scrophulariaceae and Solanaceae; and in the Liliopsida class, we found the Commelinaceae and Poaceae families. The families that presented the highest relative frequencies were Amaranthaceae (16.67\%), Convolvulaceae (12.5\%), Rubiaceae (12.5\%) and Poaceae (12.5\%) (Table 1). CARDOSO et al. (2010) and RAIMONDI et al. (2014) reported the occurrence of these families infesting naturally colored fiber cotton (BRS Safira) in Missão Velha (CE, Brazil) and white fiber cotton in Chapadáo do Sul (MS, Brazil), respectively.

The most frequent weed species were Amaranthus spp., with $13.79 \%$, and A. tenella, Ipomea spp., R. brasiliensis and $E$. indica, with $10.34 \%$ each (Table 1). CORREA; SHARMA (2004), FREITAS et al. (2006) and CHRISTOFFOLETI et al. (2011) also reported these species as competing with cotton.

During the collection period (Fig. 1), two species were collected four times (Amaranthus spp. and R. brasiliensis), four species were collected three times (A. tenella, E. indica, Ipomoea spp. and $S$. latifolia), two species were present in two sampling (N.physaloides and S. obtusifolia), and seven species were collected only once (C. hirta, C. benghalensis, Conyza spp., E. heterophylla, P. oleracea, S. dulcis and $S$. oleraceus). In April, the species with the highest whitefly incidence were E. heterophylla (154) and N. physaloides (149); in May, S. latifolia (47); and in June, C. hirta (117) (Fig. 1). May was the month in which fewer species were collected (seven); this may have been influenced by the 
crop management practices executed in the area, such as weeding. The frequency variability of the collected species made it impossible to perform a statistical analysis capable of determining which were the preferred species of oviposition for the whitefly.
The plants were collected after the weed-competition period, which starts 15 days after plant emergence (DAE) and closes at 70 DAE (CHRISTOFFOLETI et al., 2011). However, in May and June the cotton was in the phase of its fruit branches filling out and bolls opening, meaning the crop

Table 1. Weed community in the FM 975 WS cultivar cotton crop from April to June 2015, Sinop, Mato Grosso, Brazil.

\begin{tabular}{|c|c|c|c|}
\hline Family & Relative frequency (\%) & Species & Relative frequency (\%) \\
\hline \multirow{2}{*}{ Amaranthaceae } & \multirow{2}{*}{16.67} & Alternanthera tenella & 10.34 \\
\hline & & Amaranthus spp. & 13.79 \\
\hline \multirow{2}{*}{ Asteraceae } & \multirow{2}{*}{8.33} & Conyza spp. & 3.45 \\
\hline & & Sonchus oleraceus & 3.45 \\
\hline Convolvulaceae & 12.50 & Ipomea spp. & 10.34 \\
\hline \multirow{2}{*}{ Euphorbiaceae } & \multirow{2}{*}{8.33} & Chamaesyce hirta & 3.45 \\
\hline & & Euphorbia heterophylla & 3.45 \\
\hline Fabaceae & 8.33 & Senna obtusifolia & 6.90 \\
\hline Portulacaceae & 4.17 & Portulaca oleracea & 3.45 \\
\hline \multirow{2}{*}{ Rubiaceae } & \multirow{2}{*}{12.50} & Richardia brasiliensis & 10.34 \\
\hline & & Spermacoce latifolia & 6.90 \\
\hline Scrophulariaceae & 4.17 & Scoparia dulcis & 3.45 \\
\hline Solanaceae & 8.33 & Nicandra physaloides & 6.90 \\
\hline Commelinaceae & 4.17 & Commelina benghalensis & 3.45 \\
\hline Poaceae & 12.50 & Eleusine indica & 10.34 \\
\hline
\end{tabular}

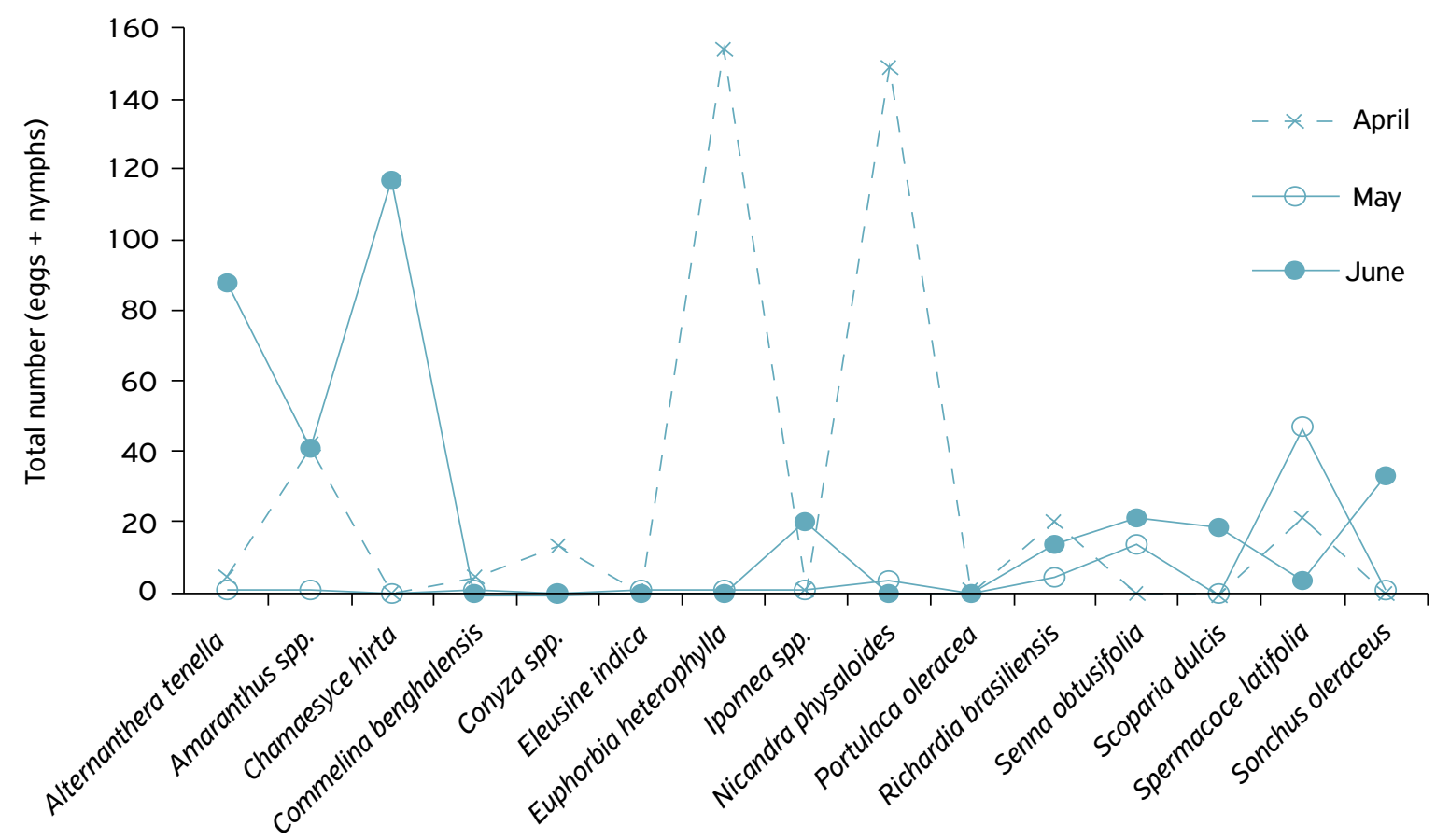

Weeds species

Figure 1. Bemisia tabaci biotype B fluctuation in the weeds present in the FM 975 WS cultivar cotton crop from April to June 2015 , Sinop, Mato Grosso, Brazil. 
was still susceptible to the pest and requiring a lot of attention. So, the whiteflies did not leave the weeds and infest the crop, increasing its population to the point of interfering in the plume quality due to honey dew deposition.

The presence of whitefly eggs or nymphs was only not observed in $P$. oleracea and E. indica among the 15 species present in the area. Corroborating the results presented in this study, VILLAS BOAS et al. (2003), SIMMONS et al. (2008), ABDRABOUD; SIMMONS (2010) and SOTTORIVA et al. (2014) also reported the plants E. heterophylla, S. obtusifolia, S. oleraceus, C. hirta, C. benghalensis, and Ipomoea spp. as whitefly hosts.

The highest $B$. tabaci incidence occurred in the glabra $E$. heterophylla plant (154) (Fig. 1); the same fact was verified by GACHOKA et al. (2005) and SOTTORIVA et al. (2014). In some studies, it is reported that the whitefly prefers ovipositing in pubescent plants (CHU et al., 2001, CETINTAS; MCAUSLANE, 2009). In other studies, it was not possible to establish a positive correlation between trichome density and number of whitefly eggs (BOIÇA JÚNIOR et al., 2007, JINDAL; DHALIWAL, 2011). According to PROCÓPIO et al. (2004), the E. heterophylla plant is characterized for being more efficient in using nitrogen $(\mathrm{N})$ absorbed in the soil than soybean and bean plants. It is probably this plant's intrinsic capacity makes it so attractive to the whitefly, since nitrogen is one of the constituent elements of the essential amino acids present in the phloem sap, which are vital for the insect's life cycle. The direct relationship between nitrogen applied to the soil and the population increase of sucking insects such as whiteflies is a fact, but it is not yet clear how this fertilization influences population growth (BI et al., 2005; IDRISS et al., 2015).

If on the one hand weeds can be used as food sources and shelter for the whitefly turning into a pest outbreak within the crop, on the other hand they act as reservoirs of biological control agents (predators, parasitoids and entomopathogens). In this study, we found nymphs in the fourth instar parasitized by an Aphelinidae parasitoid in the species Amaranthus spp., $R$. brasiliensis and $A$. tenella. NAVEED et al. (2007) consider that conserving these natural enemies around the crop can help reduce the whitefly population.

Thirteen weed species, namely Amaranthus spp., A. tenella, C. benghalensis, C. hirta, Conyza spp., E. heterophylla, Ipomea spp., N. physaloides, R. brasiliensis, S. dulcis, S. obtusifolia, $S$. oleraceus and $S$. latifolia, which were growing within the cotton crop, are alternative whitefly (B. tabaci biotype B) hosts in the municipality of Sinop. Based on the information obtained in this work, farmers can structure a management plan aiming to reduce the incidence of host weeds either in the harvest or in the off season, monitoring them and eliminating them if necessary.

\section{ACKNOWLEDGMENTS}

The authors thank André Filipiaki for the support in installing and executing the experiment, and EMBRAPA for funding the project SEG EMBRAPA (PA no. 02.11.07.005.00.04).

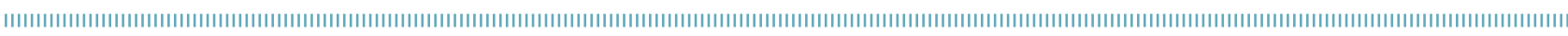
REFERENCES

ABD-RABOUD, S.; SIMMONS A. M. Survey of reproductive host plants of Bemisia tabaci (Hemiptera: Aleyrodidae) in Egypt, including new host records. Entomological News, v. 121, n.5, p.456-465, 2010.

ARAÚJO, L.H.A.; BLEICHER, E. Manejo da mosca-branca Bemisia tabaci biótipo B na cultura do algodão. In: HAJI, F.N.P.; BLEICHER, E. (Ed.). Avanços no manejo da mosca-branca Bemisia tabaci biótipo $B$ (Hemiptera: Aleyrodidae). Petrolina: Embrapa SemiÁrido, 2004. cap. 6, p73-85.

BI, J.L.; LIN, D.M.; LII, K.S.; TOSCANO, N.C. Impact of cotton planting date and nitrogen fertilization on Bemisia argentifolii populations. Insect Science, v. 12, n. 1, p.31-36, 2005.

BOIÇA JÚNIOR, A.L.; CAMPOS, Z.R.; LOURENÇÃO, A.L.; CAMPOS, A.R. Adult attractiveness and oviposition preference of Bemisia tabaci (Genn.) (Homoptera: Aleyrodidae) B-biotype in cotton genotypes. Scientia Agricola, v.64, n.2, p.147$151,2007$.
CARDOSO, G.D.; ALVES, P.L.; BELTRÃO, N.E.; DO VALE, L.S. Períodos de interferência das plantas daninhas em algodoeiro de fibra colorida 'BRS Safira'. Revista Ciência Agronômica, v.41, n.3, p.456-462, 2010.

CETINTAS, R.; MCAUSLANE, H. Effectiveness of parasitoids of Bemisia tabaci (Hemiptera: Aleyrodidae) on cotton cultivars differing in leaf morphology. Florida Entomologist, v.92, n.4, p.538-547, 2009.

CHRISTOFFOLETI, P.J.; CARVALHO, S.J.P.; NICOLAI, M.; SOUZA, R.C. Manejo de plantas daninhas na cultura do algodão. In: FREIRE, E.C. (Ed.). Algodão no cerrado do Brasil. 2. ed. Goiania: Mundial, 2011 . cap. 17, p.613-638.

CHU, C.C.; FREEMAN, T.P.; BUCKNER, J.S.; HENNEBERRY, T.J.; NELSON, D.R.; NATWICK, E.T. Susceptibility of upland cotton cultivars to Bemisia tabaci Biotype B (Homoptera: Aleyrodidae) in relation to leaf age and trichome density silverleaf whitefly studies: effects of trichome density and leaf shape. Annals of the Entomological Society of America, v.94, n.5, p.743-749, 2001. 
CORREA, J.C.; SHARMA, R.D. Produtividade do algodoeiro herbáceo em plantio direto no Cerrado com rotação de culturas. Pesquisa Agropecuária Brasileira, v.39, n. 1, p.41-46, 2004.

FREITAS, R.S.; BERGER, P.G.; FERREIRA, L.R.; SILVA, A.C.; CECON, P.R.; SILVA, M.P. Manejo de plantas daninhas na cultura do algodoeiro em sistema de plantio direto. Planta Daninha, v.24, n.2, p.339-346, 2006

GACHOKA, K.K.; OBENG-OFORI, D.; DANQUAH, E.Y. Host suitability of two Ghanaian biotypes of Bemisia tabaci (Homoptera: Aleyrodidae) on five common tropical weeds. International Journal of Tropical Insect Science, v.25, n.4, p.236-244, 2005.

IDRISS, M.H.; EL-MENIAWI, F.A.; RAWASH, I.A.; SOLIMAN, A.M. Effects of different fertilization levels of tomato plants on population density and biometrics of the cotton whitefly, Bemisia tabaci (Gennadius) (Hemiptera: Sternorrhyncha: Aleyrodidae) under greenhouse conditions. Middle East Journal of Applied Sciences, v.5, n.3, p.759-786, 2015.

JINDAL, V.; DHALIWAL, G.S. Mechanisms of resistance in cotton to whitefly (Bemisia tabaci): antixenosis. Phytoparasitica, v.39, n.2, p.129-136, 2011

LORENZI, H. Manual de identificação e controle de plantas daninhas: plantio direto e convencional. 7. ed. Nova Odessa: Instituto Plantarum, 2014. 783p.

MOREIRA, H.J.C.; BRAGANÇA, H.B.N. Manual de identificação de plantas infestantes - cultivos de verão. Campinas: FMC, 2010. 642p.

MUELLER-DOMBOIS, D.; ELLENBERG, H. Aims and methods of vegetation ecology. New York: John Wiley \& Sons, 1974. 547p.

NAVEED, M.; SALAM, A.; SALEEM, A.M. Contribution of cultivated crops, vegetables, weeds and ornamental plants in harboring of Bemisia tabaci (Homoptera: Aleyrodidae) and associated parasitoids (Hymenoptera: Aphelinidae) in cotton agroecosystem in Pakistan. Journal of Pest Science, v.80, n.4, p.191-197, 2007.
PROCÓPIO, S.O.; SANTOS, J.B.; PIRES, F.R.; SILVA, A.A.; MENDONÇA, E.S. Absorção e utilização do nitrogênio pelas culturas da soja e do feijão e por plantas daninhas. Planta Daninha, v.22, n.3, p.365-374, 2004.

RAIMONDI, M.A.; OLIVEIRA, J.R.; CONSTANTIN, J.; FRANCHINI, L.H.; BIFFE, D.F.; BLAINSKI, É.; RAIMONDI, R.T. Períodos de interferência das plantas daninhas na cultura do algodão em semeadura adensada na safrinha. Planta Daninha, v.32, n.3, p.521-532, 2014.

SANTOS, H.G.; JACOMINE, P.K.; DOS ANJOS, L.H.; OLIVEIRA, J.B.; COELHO, M.R.; LUMBRERAS, J.F.; CUNHA, T.J. Sistema brasileiro de classificação de solos. 2. ed. Rio de Janeiro: Embrapa Solos, 2006. 306p.

SIMMONS, A.M.; HARRISON, H.F.; LING, K.S. Forty-nine new host plant species for Bemisia tabaci (Hemiptera: Aleyrodidae). Entomological Science, v.1 1, n.4, p.385-390, 2008.

SOTTORIVA, L.D.M.; LOURENÇÃO, A.L.; COLOMBO, C.A. Performance of Bemisia tabaci (Genn.) Biotype B (Hemiptera: Aleyrodidae) on Weeds. Neotropical Entomology, v.43, n.6, p.574-581, 2014.

SUASSUNA, N.D.; COUTINHO, W.M. Manejo das principais doenças do algodoeiro no cerrado brasileiro. In: FREIRE, E.C. (Ed.). Algodão no cerrado do Brasil. 3. ed. Brasília: Gráfica e Editora Positiva, 2015. cap. 10, p.365-408.

TERRA, W.R.; FERREIRA C. Fisiologia molecular e evolutiva do processo digestivo dos insetos. In: PANIZZI, A.R.; PARRA, J.R.P. (Ed.). Bioecologia e nutrição dos insetos. Base para o manejo integrado de pragas. Brasília: Embrapa Informação Tecnológica, 2009. cap. 4, p.175-249.

VILLAS BÔAS, G.L.; FRANÇA, F.H.; MACEDO, N.; MOITA, A.W. Avaliação de plantas daninhas como possíveis hospedeiras de mosca-branca. Horticultura Brasileira, v.2 1, n.2, p.344, 2003.

YAMASHITA, O.M.; MENDONÇA, F.S.; ORSI, J.V.; RESENDE, D.D.; KAPPES, C.; GUIMARÃES, S.C. Efeito de doses reduzidas de oxyfluorfen em cultivares de algodoeiro. Planta Daninha, v.26, n.4, p.917-921, 2008. 